\title{
The gearing adjustment in inflation accounting: the financing sequence assumption
}

\author{
M.A. van Hoepen \\ Touche Ross Netherlands/Touche Ross International, 700 van Alkemade Avenue, 2597 AW the Hague, The Netherlands \\ I.J. Lambrechts* and F.J. Mostert \\ Department of Business Economics, University of Stellenbosch, Stellenbosch, 7600 Republic of South Africa
}

Accepted 23 February 1989

\begin{abstract}
The application of a gearing adjustment in inflation accounting has always resulted in the problem of determining a financing sequence. A decision has to be taken whether certain categories of assets are financed with equity and/or loan capital. Financial theory of the last few decades quite convincingly revealed that there are no logical grounds for relating certain assets to certain liabilities and/or equity. This proportional financing assumption is discussed and illustrated in the article for the so-called Van der Schroeff-system of income demermination in order to point out the sensitivity and financial consequences of this assumption for financial decision making. The assumption about the financing sequence does have a definite influence on the gearing adjustment. Further influences are on the income statement and the message given to shareholders and the investment public; the composition of the asset structure and consequently the risk composition of the assets; the composition of the financing structure and consequently the financial risk as portrayed by the balance sheet; and the marginal financing ratios needed to maintain the original gearing ratio.
\end{abstract}

Die toepassing van die hefboomaansuiwering by inflasierekeningkunde het altyd 'n probleem tot gevolg, naamlik om die volgorde van finansiering te bepaal. 'n Besluit moet geneem word of sekere kategorieë van bates met eie kapitaal en/of leningskapitaal gefinansier moet word. Finansiële teorie van die laaste aantal dekades het tot gevolg gehad dat daar geen logiese basis is om sekere bates aan sekere laste of eie hapitaal te koppel nie. Die proporsionele finansieringsaanname word in hierdie artikel bespreek vir die sogenaamde Van der Schroeff-sisteem van inkomstebepaling om sodoende die sensitiwiteit en finansiële gevolge van hierdie aanname vir finansiële besluitneming uit te wys. Die aanname in verband met die finansieringsvolgorde het 'n definitiewe invloed op die hefboomaansuiwering. Verdere gevolge is op die inkomstestaat en die boodskap wat deurgegee word aan die aandeelhouers en die beleggerspubliek; die samestelling van die batestruktuur en gevolglik die risikosamestelling van die bates; die samestelling van die finansieringstruktuur en dus ook die finansiële risiko soos weergegee deur die balansstaat; en die marginale finansieringsverhoudings om die aanvanklike hefboomverhouding te handhaaf.

* To whom correspondence should be addressed

\section{Introduction}

The application of a gearing adjustment in inflation accounting has always resulted in a problem of determining a financing sequence. There is a rather long standing history in the Netherlands underlying the incorporation of financing in the application of current cost systems. A decision has to be taken whether certain categories of assets are financed with equity and/or loan capital. Financial theory of the last few decades quite convincingly revealed that there are no logical grounds for relating certain assets to certain liabilities and/or equity. The financing-sequence in the application of a gearing adjustment must therefore be determined on practical grounds. The economic consequences of this choice have never been paid much attention, neither in theory nor in practice.

There are two examples in which the choice of a particular assupmtion about the financing sequence was made more or less explicitly on the basis of practical consequences. The first is the one in which the exact financing sequence assumption depends on a perceived Modigliani and Miller-like optimal financial structure. In this assumption all value increases (revaluations) are added to equity capital and not regarded as distributable income (or income attributable to shareholders). An addition to equity capital can be justified because of the (general or specific) purchasing power loss on (net) monetary assets.

Another example of a financing sequence, that has obviously been chosen on the basis of its economic consequences, is the so-called Hofstra system. In the Netherlands there was a government committee under the chairmanship of Prof. Hofstra whose aim was to make proposals for a tax system that should be neutral as to inflation. Apart from some minor changes in the tax law, the proposals of the Hofstra committee have never been implemented. The assumed financing sequence in the Hofstra proposals is that equity capital is used primarily to finance assets for which the generated income is not taxable. An example of these assets are investments which are tax free. If equity capital is more than these tax-exempt assets, the surplus is used to finance stocks which are valued either by a LIFO-system or a base-stock system (both methods being used for tax purposes in the Netherlands). In this way a complete sequence is proposed, ending with monetary assets, e.g. debtors and cash. The aim and consequence of this proposed financing sequence are clear. If equity capital serves (primarily) to finance tax-exempt assets, there is no need to allow an inflation correction for income generated by those assets, because that part of income is not taxable. If equity capital next serves to finance stocks 
valued by a LIFO-system or base-stock system, there is no need to correct taxable income for inflation, because in the ordinary course of business there are no inflationary effects (value increases) in taxable income generated by those assets.

In the absence of a logically/theoretically based assumption about the financing sequence, a proportional sequence can be assumed, that is every individual asset is financed with loan capital and equity capital in the same proportion as total loan capital and total equity capital (at the beginning of the year or at the end of the year or an average). This proportional financing assumption will be discussed and illustrated in this article for the socalled Van der Schroeff system of income determination in order to point out the sensitivity and financial consequences of this assumption for financial decision making.

\section{The proportional financing sequence in the Van der Schroef system}

The Van der Schroeff income determination system has never been applied in practice. Nevertheless, there are two reasons for using the Van der Schroeff system as an example of the application of a gearing adjustment based on a proportional financing assumption. First, it is the only well-described system that explicitly uses a proportional financing assumption. Second, the system is a splendid example of one that is constructed in view of economic consequences (i.e. to maintain capital intact).

Van der Schroeff gradually developed Limperg's replacement value theory to a current cost accounting system. Contrary to the Limperg system Van der Schroeff applies no backlog depreciation and introduces a gearing adjustment.

The ultimate outcome of Van der Schroeff's trail of thought was published after his death. He explicitly states the maintenance aim(s) of his income determination system, which can be described as follows:

1. maintenance of the specific purchasing power of equity capital used to finance a normal stock of nonmonetary assets;

2. maintenance of the general purchasing power of equity capital used to finance other assets (that is speculative stock and monetary assets); and 3. nominal capital maintenance of loan capital.

\section{Example}

The opening balance sheet of a company reads: Balance sheet on $1 / 1 / 19 \times 0$

\begin{tabular}{|c|c|c|}
\hline Share capital & R500100kg material A@ & R1000 \\
\hline Loan capital & 1500 Cash & 1000 \\
\hline & R2 000 & R2 000 \\
\hline
\end{tabular}

Normal stock of material $A$ is $80 \mathrm{~kg}$. The current cost of material $A$ on $1 / 1 / 19 \times 0$ is $R 10$ per $\mathrm{kg}$. During the year, the current cost of good A gradually increases to R12 (specific price increase: $20 \%$ ). The general consumer index of 100 on $1 / 1 / 19 \times 0$ gradually increases to 110 at the end of the year (general price increase: 10\%). There are no sales and purchasing transactions in $19 \times 0$.

As said before, Van der Schroeff uses a proportional financing assumption (according to the opening balance sheet), so it is assumed that material $A$ is financed with

$$
\frac{500}{2000} \times \frac{100}{1}=25 \%
$$

equity capital, and $75 \%$ loan capital. Likewise, the amount of cash is assumed to have been financed with $25 \%$ equity capital and $75 \%$ loan capital.

The necessary additions to the revaluation surplus in order to arrive at the three-fold maintenance aim are:

1. specific price increase of equity capital used to finance normal stock:

$$
0,20 \times \frac{500}{2000} \times(80 \times 10) \quad=R 40
$$

2. general price increase of equity capital used to finance other assets:

$$
\begin{aligned}
& \text { speculative stock: } 0,10 \times \frac{500}{2000} \times(20 \times 10)=5 \\
& \text { monetary assets: } 0,10 \times \frac{500}{2000} \times 1000=25
\end{aligned}
$$

3. price decrease of loan capital:

$$
\begin{array}{lc}
0,0 \times 1500= & 0 \\
\text { Total necessary addition to revaluation surplus } & \overline{\mathrm{R}} 70
\end{array}
$$

The following can easily be seen.

1. The necessary addition to the revaluation surplus can also be calculated as the general price increase multiplied by the total equity capital plus the difference between the specific price increase and the general price increase multiplied by that amount of normal stock that is supposed to have been financed with equity capital, i.e.:

$$
\begin{array}{ll}
0,10 \times 500 & =50 \\
(0,20-0,10) \times(80 \times 10) \frac{500}{2000} & =20 \\
& \frac{R}{\mathrm{R} 70}
\end{array}
$$

2. the amount of the initial capital that must be maintained is equity capital invested in normal stock

$$
\frac{500}{2000} \times(80 \times 10)
$$


equity capital invested in other assets

$$
\begin{aligned}
& \frac{500}{2000} \times[(20 \times 10)+1000] \\
& \text { loan capital }
\end{aligned}
$$

Total capital to be maintained

The above amount must increase to:

200 (normal stock) $\times 1,2=$

300 (equity less normal stock) $\times 1,1=$

1500 (loan capital) $\times 1,0=$

Capital maintained at end of period

The necessary addition to the revaluation surplus takes place in two steps.

1. Of the total value increase of stock (R200) an amount of $R 40$ is added to the revaluation surplus. The remainder of the value increase is in principle income, but will be treated so only after realization (by way of sales transactions). In the example the full R160 is regarded as an unrealized speculative and financing (gearing) gain. The value increase of $R 200$ can be

\begin{tabular}{|c|c|c|c|}
\hline \multirow{4}{*}{$\begin{array}{c}\text { Total value } \\
\text { increase of } \\
\text { stock } 100 \times 2 \\
=\mathbf{R} 200\end{array}$} & \multirow{2}{*}{$\begin{array}{c}\text { Value increase } \\
\text { of normal stock } \\
80 \times 2=160\end{array}$} & $\begin{array}{c}25 \% \text { financed } \\
\text { with equity } \\
\text { R40 }\end{array}$ & $\begin{array}{c}\text { Addition to } \\
\text { revaluation } \\
\text { surplus }\end{array}$ \\
\hline & & $\begin{array}{l}75 \% \text { financed } \\
\text { with loans } \\
\text { R120 }\end{array}$ & $\begin{array}{c}\text { Unrealized } \\
\text { financing } \\
\text { gain }\end{array}$ \\
\hline & \multirow{2}{*}{$\begin{array}{c}\text { Value increase of } \\
\text { speculative stock } \\
20 \times 2=R 40\end{array}$} & $\begin{array}{c}25 \% \text { financed } \\
\text { with equity } \\
\text { R10 }\end{array}$ & $\begin{array}{l}\text { Unrealized } \\
\text { speculative } \\
\text { gain }\end{array}$ \\
\hline & & $\begin{array}{c}75 \% \text { financed } \\
\text { with loans } \\
=\mathrm{R} 30\end{array}$ & $\begin{array}{c}\text { Unrealized } \\
\text { speculative/ } \\
\text { financing gain }\end{array}$ \\
\hline
\end{tabular}
analysed as follows:

2. There is an addition to the revaluation surplus of $\mathbf{R} 30$, in order to maintain the general purchasing power of equity capital invested in 'other assets'. The total value increase (specific price increase) of speculative stock is regarded as income and charged to the income statement. The balance sheet on $31 / 12 / 19 \times 0$ will therefore read:

Balance sheet on $31 / 12 / 19 \times 0$

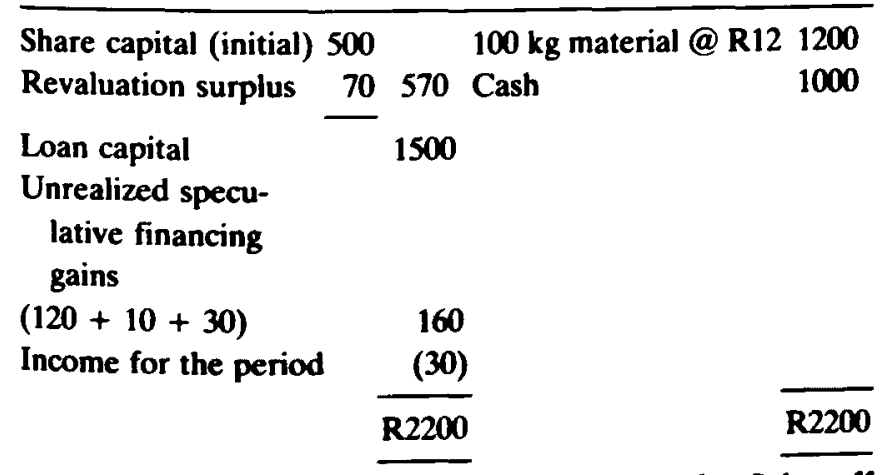

It is not the intention to discuss the Van der Schroeff system as such. The way in which, for instance, the financing or speculative gains are considered to be realized (FIFO-sequence or LIFO-sequence) and other problems with the application of the Van der Schroeff system are not discussed. It is the sole intention to illustrate only the consequences of the proportional financing sequence.

\section{The Van der Schroeff system under a diffenent financing assumption}

The system is very sensitive to the applied financing sequence. In order to illustrate this the financing assumption is being changed and it is assumed that the monetary assets are primarily financed by monetary liabilities. If the proportional financing assumption is applied the opening balance sheet can be regarded as two partial balance sheets: the equity capital balance sheet and the loan capital balance sheet.

\begin{tabular}{|c|c|c|c|}
\hline \multirow[t]{2}{*}{ Equity capital } & \multicolumn{2}{|c|}{$\begin{array}{l}500 \text { Normal stock: } \\
25 \% \times 80 \times 10= \\
\text { Speculative stock: } \\
25 \% \times 20 \times 10= \\
\text { Monetary assets: } \\
25 \% \times 1000=\end{array}$} & $\begin{array}{r}200 \\
50 \\
250\end{array}$ \\
\hline & $\mathbf{R 5 0 0}$ & & $\mathbf{R S O 0}$ \\
\hline \multicolumn{4}{|c|}{ Loan capital balance sheet on $1 / 1 / 19 \times 0$} \\
\hline Loan capital & & $\begin{array}{l}\text { Normal stock: } \\
75 \% \times 80 \times 10= \\
\text { Speculative stock: } \\
75 \% \times 20 \times 10= \\
\text { Monetary assets: } \\
75 \% \times 1000=\end{array}$ & 150 \\
\hline & 1500 & & R 1500 \\
\hline
\end{tabular}

Equity balance sheet on $1 / 1 / 19 \times 0$

If the assumption of proportional financing is changed and it is assumed that monetary assets are primarily financed by monetary liabilities, the balance sheet on 1/1/19x0 will be as follows:

Balance sheet on $1 / 1 / 19 \times 0$

\begin{tabular}{llll}
\hline Equity capital & 500 Normal stoct $80 \times 10=$ & 800 \\
Net monetary liabilities & 500 Speculative stoct $20 \times 10=$ & 200 \\
\cline { 2 - 2 } & R1000
\end{tabular}

Under this different assumption normal stock turns out not to be financed $50 \%$ but $25 \%$ by equity (as under the proportional financing sequence). The necessary additions to revaluation surplus are consequently:

1. maintenance of the specific purchasing power of equity capital invested in normal stock:

$0,20 \times 0,5 \times 800 \quad=80$

2. maintenance of the general purchasing power of equity capital invested in 'other assets' (speculative stock):

$0,10 \times 0,5 \times 200$

$=10$

3. capital maintenance of loan capital

net monetary liabilities:

$500 \times 0,00$ 
Total necessary addition to the revaluation surplus

The (unrealized) speculative and financing gains are as follows:

\begin{tabular}{|c|c|c|c|}
\hline \multirow{4}{*}{$\begin{array}{c}\text { Total value } \\
\text { increase of } \\
\text { stock } \\
100 \times 2 \\
=\mathrm{R} 200\end{array}$} & \multirow{2}{*}{$\begin{array}{l}\text { Value increase } \\
\text { of normal stock } \\
80 \times 2=\mathrm{R} 160\end{array}$} & $\begin{array}{c}50 \% \text { financed } \\
\text { with equity } \\
=\mathrm{R} 80\end{array}$ & $\begin{array}{l}\text { Addition to } \\
\text { revaluation } \\
\text { surplus }\end{array}$ \\
\hline & & $\begin{array}{c}50 \% \text { financed } \\
\text { with loans } \\
=\mathrm{R} 80\end{array}$ & $\begin{array}{l}\text { Unrealized } \\
\text { financing } \\
\text { gain }\end{array}$ \\
\hline & \multirow{2}{*}{$\begin{array}{c}\begin{array}{c}\text { Value increase } \\
\text { of speculative } \\
\text { stock }\end{array} \\
20 \times 2=R 40\end{array}$} & $\begin{array}{c}50 \% \text { financed } \\
\text { with equity } \\
=\mathrm{R} 20\end{array}$ & $\begin{array}{l}\text { Unrealized } \\
\text { speculative } \\
\text { gain }\end{array}$ \\
\hline & & $\begin{array}{c}50 \% \text { financed } \\
\text { with loans } \\
=\mathrm{R} 20\end{array}$ & $\begin{array}{l}\text { Unrealized } \\
\text { speculative/ } \\
\text { financing gain }\end{array}$ \\
\hline
\end{tabular}

As a result the balance sheet at the end of the period becomes:

Balance sheet on $31 / 1 / 19 \times 0$

\begin{tabular}{lccc}
\hline Share capital (initial) & 500 & $100 \mathrm{~kg}$. A @ R12 & 1200 \\
Revaluation surplus & 90 & 590 Cash & 1000 \\
\cline { 2 - 3 } $\begin{array}{l}\text { Loan capital } \\
\text { Unrealized speculative } \\
\quad\end{array}$ & 1500 & \\
$\begin{array}{l}\text { financing gains } \\
(80+20+20)\end{array}$ & 120 & \\
Income for the period & $(10)$ & \\
& $\quad \mathrm{R} 2200$ & $\mathrm{R} 2200$ \\
\hline
\end{tabular}

\section{The influence of the financing assumption}

After the $100 \mathrm{~kg}$ of material A have been sold (thus realizing the financing and speculative gains) and income distributed, it is obvious that under the proportional financing assumption the gearing ratio will be equity capital: loan capital $=570: 1500$

Under the second financing assumption the gearing ratio becomes equity capital: loan capital $=590: 1500$

The financing assumption also has a very specific influence on the composition of the assets and the financial structures as is clear from Table 1.

From Table 1 it is clear that the marginal financing ratios to maintain the orginal gearing ratio $(25 \%)$ differ considerably from the original situation, i.e. $9,1 \%$ equity to total capital for the proportional financing (30/330) and $3,2 \%$ for the second financing assumption (10/310).

\section{Conclusion}

The assumption about the financing sequence does have a definite influence on the gearing adjustment. The result of this difference in influence will further influence:

- the income statement and the message given to shareholders and the investment public;

- the composition of the asset structure and consequently the risk composition of the assets;

- the composition of the financing structure and consequently the financial risk as portrayed by the balance sheet; and

- the marginal financing ratios to maintain the original gearing ratio.

The economic consequences of the financing sequence assumption are therefore often hidden. The proportional

Table 1 Influence of the financing assumption

\begin{tabular}{|c|c|c|c|c|c|c|c|}
\hline & $\begin{array}{l}\text { Normal } \\
\text { stock }\end{array}$ & $\begin{array}{l}\text { Speculative } \\
\text { assets }\end{array}$ & $\begin{array}{l}\text { Monetary } \\
\text { assets }\end{array}$ & $\begin{array}{l}\text { Total } \\
\text { assets }\end{array}$ & Equity & Loans & Total \\
\hline \multicolumn{8}{|c|}{$\begin{array}{l}\text { Situation after the sale and } \\
\text { replacement of the assets and } \\
\text { proportional financing: }\end{array}$} \\
\hline Amounts in Rand & 960 & 240 & 870 & 2070 & 570 & 1500 & 2070 \\
\hline Percentages & $46,4 \%$ & $11,6 \%$ & $42,0 \%$ & $100 \%$ & $27,5 \%$ & $72,5 \%$ & $100 \%$ \\
\hline \multicolumn{8}{|l|}{$\begin{array}{l}\text { Situation under second } \\
\text { financing assumption }\end{array}$} \\
\hline Amounts in Rand & 960 & 240 & 890 & 2090 & 590 & 1500 & 2090 \\
\hline Percentages & $45,9 \%$ & $11,5 \%$ & $42,6 \%$ & $100 \%$ & $20,2 \%$ & $71,8 \%$ & $100 \%$ \\
\hline \multicolumn{8}{|c|}{$\begin{array}{l}\text { Changes in financial structure } \\
\text { to maintain the original percentages }\end{array}$} \\
\hline \multicolumn{8}{|l|}{ Proportional financing: } \\
\hline Amounts of changes & $\mathbf{0}$ & 0 & 330 & 330 & 30 & 300 & 330 \\
\hline New amounts & 960 & 240 & 1200 & 2400 & 600 & 1800 & 2400 \\
\hline Percentages & $40 \%$ & $10 \%$ & $50 \%$ & $100 \%$ & $25 \%$ & $75 \%$ & $100 \%$ \\
\hline \multicolumn{8}{|c|}{ Second financing assumption: } \\
\hline Amounts of changes & $\mathbf{0}$ & 0 & 310 & 310 & 10 & 300 & 310 \\
\hline New amounts & 960 & 240 & 1200 & 2400 & 600 & 1800 & 2400 \\
\hline Percentages & $40 \%$ & $10 \%$ & $50 \%$ & $100 \%$ & $25 \%$ & $75 \%$ & $100 \%$ \\
\hline
\end{tabular}


financing assumption is not as neutral as it might look at first glance. A careful analysis should therefore be conducted before a specific assumption is made.

\section{References}

Accounting Practices Committee. 1978. RE201: Guidelines on disclosure of effects of changing prices on financial results. The Institute of Chartered Accountants (SA).
Hofstra, H.J. 1978. Inflatieneutrale Belastingheffing. Staatsuitgevery, 's-Gravenhage.

Kleerekoper, I. 1983. Information reflecting the effects of chancing prices. Maandblad voor Accountancy en Bedryfshuishoudkunde, vol.57, February, 2-51 - 2-65.

Van der Schroeff, H.J. 1969. Winstbepaling en financieringsstructuur. Maandblad voor Accountancy en Bedryfshuishoudkunde., vol. 43, February, 50 - 72. 